\title{
ARAŞTIRMA / RESEARCH \\ Üniversite öğrencilerinin ilişkilerle ilgili bilişsel çarpıtmaları ve öfke ifade tarzları
}

Cognitive distortions about relationships and anger expression styles of university students

Arzu Yüksel1 (D), Emel Bahadır-Yilmaz (D)

${ }^{1}$ Aksaray University, Faculty of Health Sciences, Department of Psychiatric Nursing, Aksaray, Turkey.

${ }^{2}$ Giresun University, Faculty of Health Sciences, Department of Psychiatric Nursing, Giresun, Turkey.

\begin{abstract}
Purpose: The aim of this study was to assess cognitive distortions about relationships and anger management styles of university students.

Materials and Methods: In this study, a cross-sectional and analytical design was used. The sample of the study consisted of 335 nursing and 152 health management students $(\mathrm{n}=487)$. Data were collected using a Student Demographic Form, Interpersonal Cognitive Distortions Scale (ICDS), and Trait Anger-Anger Expression Styles (TA-AES).

Results: The study found that the students' average total ICDS score was $50.27 \pm 10.63$, and their mean sub-scale scores were $21.77 \pm 5.80$ for trait anger, $22.76 \pm 4.70$ for anger which was kept under control, $16.78 \pm 4.58$ for expressed anger, and $17.05 \pm 4.31$ for suppressed anger. It was determined that there was a positive, moderately strong correlation between the ICDS and the TA-AES.

Conclusion: The present study has demonstrated that the students' cognitive distortions about relationships are associated with their trait anger-anger expression styles. In the light of these findings, it is suggested that mindfulnessbased cognitive-behavioral approaches should be implemented to solve the students' cognitive disorders and anger-related problems.
\end{abstract}

Keywords: Interpersonal relationship, anger, cognitive distortion, nursing, health management

\section{Öz}

Amaç: $\mathrm{Bu}$ çalışma üniversite öğrencilerinin kişilerarası ilişkilerle ilgili bilişsel çarpıtmaları ve öfke ifade tarzlarının incelenmesi amacıyla yapılmıştır.

Gereç ve Yöntem: Bu çalışmada, kesitsel ve analitik türde bir araştırma deseni kullanılmıştır. Araştırmanın örneklemi 335 hemșirelik ve 152 sağllk yönetimi bölümü öğrencisinden oluşmuştur ( $\mathrm{n}=487$ ). Veriler, "Öğrenci Bilgi Formu", "Kişilerarası Bilişsel Çarpıtmalar Ölçeği (KBÇÖ)" ve "Sürekli Öfke-Öfke Tarz Ölçeği (SÖ-ÖTÖ)" ile toplanmıștır.

Bulgular: Araştırmaya katılan öğrencilerin ilișkilerle ilgili bilişsel çarpıtmalar genel toplam puan ortalaması $50.27 \pm 10.63$ olup sürekli öfke tarzı puan ortalaması $21.77 \pm 5.80$, öfke tarzı ölçeğinin "kontrol altına alınmış öfke" boyutunda $22.76 \pm 4.70$, "dișa vurulan öfke" boyutunda $16.78 \pm 4.58$ ve "içte tutulan öfke" boyutunda 17.05 \pm 4.31 olarak saptanmıştır. İ̈BÇÖ ile SÖ-ÖTÖ arasında orta düzeyde ve pozitif yönde bir ilişki belirlenmiștir.

Sonuç: Bu çalışma, öğrencilerin ilişkilerle ilgili bilişsel çarpıtmalarının sürekli öfke-öfke ifade tarzları ile ilişkili olduğunu saptamıştır. $\mathrm{Bu}$ bulgular doğrultusunda, öğrencilerin bilișsel çarpıtmalarını ve öfke ile ilgili yaşadıkları sorunları çözmek için bilinçli farkındalık temelli bilişsel-davranışç yaklaşımların uygulanması önerilmiştir.

Anahtar kelimeler: Kișilerarası ilişkiler, öfke, bilișsel çarpıtma, hemşirelik, sağlık yönetimi

Yazışma Adresi/Address for Correspondence: Dr. Emel Bahadır Yılmaz, Giresun University, Faculty of Health Sciences, Department of Psychiatric Nursing, Giresun, Turkey. E-mail: ebahadiryilmaz@yahoo.com, emel.bahadir.yilmaz@giresun.edu.tr

Geliş tarihi/Received: 26.11.2018 Kabul tarihi/Accepted: 22.12.2018 Çevrimçi yayın/Published online: 13.03.2019 


\section{GİRİ̧̧}

Erikson'un Psikososyal Gelişim Kuramına göre Ergenlik ve Gençlik Döneminde sağlıklı bir kimlik oluşturan birey, Genç Erişkinlik Dönemine geçerek insanlarla yakın ilișkiler kurma eylemini sağlıklı bir biçimde yerine getirmek durumundadır ${ }^{1}$. Romantik ilişkiler kurma da bu dönemin önemli bir parçasıdır. İlişkilerle ilgili inançlar bireylerin bir ilişkinin nasıl olması gerektiği ile ilgili düşünceleri, ilişkilerden beklentileri ve yaşanılan olayları algılama biçimlerinden oluşmaktadır ${ }^{2}$. Yakın ilişkilerle ilgili sahip olunan irrasyonel düşünceler, bireylerin yakın ilişkilerinde zarar göreceklerini düşünmelerine ve ilişkilerinden gerçek dışı bir beklenti içine girmelerine neden olabilir. Çünkü bilişsel çarpıtmaların kişilerde otonomiyi azalttığ1, psikolojik savunma düzeneklerini zayıflattığ1 ifade edilmektedir ${ }^{3}$. Hatta değersizlik duygularına, istenilmediği, reddedildiği düşüncelerine yol açarak kişinin benlik değerinin zedelenmesine neden olabileceğinden söz edilmektedir ${ }^{4}$. Bu durum kişinin anksiyete ve öfke gibi disfonksiyonel duygular deneyimlemesine neden olabilmektedir ${ }^{5}$.

Bilişsel çarpıtmalar bazı inançlardan, tutumlar ve varsayımlardan etkilenen otomatik düşüncelerden oluşurlar. Bu inançlar ve düşünme biçimleri, çocukluktan başlayarak insanın kendisiyle, diğer insanlarla ve hatta yaşadıkları dünyayla ilişkileri sonucunda gelişirler. En temel inançlar, yaşamla ve insanlarla olan ilk etkileşimlerden biçimlenirler ve genellikle hiç sorgulanmamış olan algılardan ve fikirlerden oluşurlar. $\mathrm{Bu}$ algılar ve fikirler kişi tarafindan değişmez olarak, olduğu gibi kabul edilirler $^{6}$. Keyfi çıkarsama, seçici algılama, aşırı genelleme, abartma ve azaltma, kişiselleştirme, iki kutuplu düşünce, etiketleme, duygusal nedensellik, meli ve - malı ifadeleri ve zihin okuma gibi inançlar ya da düşünceler bilişsel çarpitmalara örnek olarak verilebilir ${ }^{7}$. Bilişsel çarpıtmaların diğer bir boyutu da ilişkilerle ilgili yaşanan bilişsel çarpıtmalardır ve ilişskilerde yaşanan bilişsel çarpıtmalar öfkeye yol açabilmektedir.

Bilişsel çarpıtmaların kişinin stresle baş etme yeteneğini olumsuz yönde etkilediği, öfkeye neden olduğu, öfkenin de ya kişiler arası ilişkilerde saldırganlığa ya da kendine zarar verme davranışına dönüşebileceği ifade edilmektedir ${ }^{8}$. Üniversite öğrencilerinin bilişsel çarpıtmaları ile öfke arasında ilişki olduğunu gösteren çalışmalar bulunmaktadır.
Kuzucu ve ark. (2015)'nın ilişkilerde bilişsel çarpıtmalar ve öz-kontrol ilişkisinde sürekli öfkenin aracılık rolünü değerlendirdikleri çalışmada, ilişkilerle ilgili bilişsel çarpıtmaların kişilerde sürekli öfke yaşanmasına neden olduğu bildirilmektedir? ${ }^{9}$. Benzer şekilde, kişilerarası ilişkilerle ilgili bilişsel çarpıtmaların öğrencilerin stres düzeylerini artırdığ belirtilmektedir ${ }^{10}$. Bir başka çalışmada ise sürekli öfke duygusu yaşayan ve öfkelerini kontrol etmekte zorlanan öğrencilerin, öfkesini daha fazla dişa vurduğu veya bastırdığından ve aynı zamanda kendisini daha çok yalnız hissettiğinden söz edilmektedir ${ }^{11}$. Diğer bir çalışmada elde edilen "romantik ilişkilerle ilgili aşırı beklenti içine girmenin, aile ve arkadaşlarla kurulan ilişkilerin bir ilişkiden alınan doyumu etkilediği" bulgusuyla da paralellik göstermektedir ${ }^{12}$. Denilebilir ki, üniversite yıllarında kurulan yakın ilişkilerle ilişkili bilişsel çarpıtmalar öfkeye, yaşanan bu öfke de kişinin ileriki yıllarda sağlıklı yakın ilişkiler kurmasında sorunlar yaşamasına neden olabilir. $\mathrm{Bu}$ nedenle, bu çalışma, üniversite öğrencilerinin kişilerarası ilişkilerle ilgili bilişsel çarpıtmaları ve öfke ifade tarzlarının incelenmesi amacıyla yapılmıştır.

\section{GEREÇ VE YÖNTEM}

Bu çalışmada, kesitsel ve analitik türde bir araştırma deseni kullanılmıştır. Araştırmanın evrenini, bir Sağlık Bilimleri Fakültesinde 2016-2017 öğretim y1lında öğrenim gören 629 öğrenci oluşturmuştur. Yapılan power analizine göre $\% 95$ güven aralığında ve $\alpha=0.05$ hata payı ile örneklem büyüklüğü 239 kişi olarak belirlenmiştir. Ancak araştırmaya katılmayı kabul eden 487 öğrenci ile araştırma tamamlanmıştır. Örneklemi oluşturan öğrencilerin yaş ortalaması 21,22 $\pm 2,11$ 'dir. Öğrencilerin \%52,2'si 21-23 yaş, $\% 38,6$ 's1 18-20 yaş grubunda yer almaktadır. Öğrencilerin \%68,8'i Hemşirelik Bölümü ve \%31,2'si Sağlık Yönetimi öğrencisidir. \%69,0’unun cinsiyeti kadın olup \%24,2'si birinci sinıf, \%25,1'i ikinci sinıf, $\% 24,4$ 'ü üçüncü sinıf ve $\% 26,3$ 'ü dördüncü sinıf öğrencisidir (Tablo 1).

Araştırmanın yapılabilmesi için ilgili Sağlık Bilimleri Fakültesi (2017/91350869) ve İnsan Araştırmaları Etik Kurulu'ndan (2017/41) yazılı izin alınmıştır. Araştırma kapsamına alınan öğrencilerden, araştırmaya ilişkin bilgilendirme yapıldıktan sonra sözlü onamları alınmıştır. 
Tablo 1. Sosyodemografik veriler

\begin{tabular}{|c|c|c|c|}
\hline \multicolumn{2}{|l|}{ Değişken } & $\mathbf{N}$ & Yüzde \\
\hline \multirow[t]{3}{*}{ Yaş } & 18-20 Yaş & 188 & 38.6 \\
\hline & 21-23 Yaş & 254 & 52.2 \\
\hline & 24 ve üzeri yaş & 45 & 9.2 \\
\hline \multirow[t]{2}{*}{ Bölüm } & Hemşirelik & 335 & 68.8 \\
\hline & Sağllk Yönetimi & 152 & 31.2 \\
\hline \multirow[t]{4}{*}{ Sinif } & Birinci sınıf & 118 & 24.2 \\
\hline & İkinci sınıf & 122 & 25.1 \\
\hline & Üçüncü sınıf & 119 & 24.4 \\
\hline & Dördüncü sınıf & 128 & 26.3 \\
\hline \multirow[t]{2}{*}{ Cinsiyet } & Kadın & 336 & 69.0 \\
\hline & Erkek & 151 & 31.0 \\
\hline \multirow[t]{4}{*}{ Mezun olduğu lise } & Temel lise & 117 & 24.0 \\
\hline & Anadolulisesi & 232 & 47.6 \\
\hline & Sağlık meslek lisesi & 85 & 17.5 \\
\hline & Meslek Lisesi & 53 & 10.9 \\
\hline \multirow[t]{2}{*}{ Bölüme isteyerek gelme durumu } & Evet & 324 & 66.5 \\
\hline & Hayır & 163 & 33.5 \\
\hline \multirow[t]{5}{*}{ Annenin eğitim düzeyi } & Okur yazar değil & 50 & 10.3 \\
\hline & Okur yazar & 27 & 5.5 \\
\hline & İlkokul/ortaokul & 312 & 64.0 \\
\hline & Lise & 59 & 12.1 \\
\hline & Üniversite & 39 & 8.0 \\
\hline \multirow[t]{5}{*}{ Babanın eğitim düzeyi } & Okur yazar değil & 13 & 2.7 \\
\hline & Okur yazar & 24 & 4.9 \\
\hline & İlkokul/ortaokul & 269 & 55.2 \\
\hline & Lise & 109 & 22.4 \\
\hline & Üniversite & 72 & 14.8 \\
\hline \multirow{3}{*}{ Ailenin gelir düzeyi } & İyi & 106 & 21.8 \\
\hline & Orta & 363 & 74.5 \\
\hline & Kötü & 18 & 3.7 \\
\hline \multirow[t]{3}{*}{ Algilanan ekonomik durum } & $\dot{\text { İyi }}$ & 106 & 21.8 \\
\hline & Orta & 325 & 66.7 \\
\hline & Kötü & 56 & 11.5 \\
\hline
\end{tabular}

\section{Veri Toplama Araçları}

\section{Öğrenci Bilgi Formu (ÖBF)}

ÖBF, araştırmacılar tarafindan alan yazın taranarak oluşturulmuş olup yaş, bölüm, sınıf, cinsiyet, mezun olduğu lise, anne ve babanın eğitim durumu, anne ve babanın mesleği, ailenin gelir düzeyi, ekonomik durumunu nasıl algıladığı, sosyal aktivitelere katılım düzeyi, arkadaş grubu, arkadaş sayısı, arkadaşlarla ilişskileri ve aile içi ilişkileri gibi bilgilere ait soruları içermektedir ${ }^{6-11}$.

\section{Kişilerarası Bilişsel Çarpıtmalar Ölçeği (KBÇÖ):}

KBÇÖ, bireylerin kişilerarası ilişkilerde sahip oldukları bilișsel çarpıtmaları ölçmek amacıyla Hamamc1 ve Büyüköztürk (2003) tarafindan geliştirilmiştir ${ }^{13}$. Ölçek 19 maddeden oluşmakta ve ölçekten alınabilecek en yüksek puan 95, en düșük puan 19'dur. Alınan yüksek puanlar bireylerin bilişsel çarpıtmaları olduğunu göstermektedir.

Ölçek üç alt boyuttan olușmaktadır. Yakınlıktan kaçınma boyutu, bireylerin ilişkilerinde yakınlık kurarlarsa zarar göreceklerine dair inanış1; gerçekçi olmayan ilişki beklentisi boyutu, bireylerin ilişkilerindeki yüksek beklenti ve standartları; zihin okuma boyutu ise zihin okuma hatasinı temsil etmektedir. Cronbach alfa katsayıs1 0,67, alt boyutlarda ise yakınlıktan kaçma 0,73, gerçekçi olmayan ilişki beklentisi 0,66, zihin okuma 0,49 olarak bulunmuştur. Bu çalışmada ölçeğin Cronbach alfa değeri 0,80, yakınlıktan kaçma alt boyutu 0,77 , gerçekçi olmayan ilișki beklentisi alt boyutu 0,73 ve zihin okuma alt boyutu 0,65 olarak bulunmuştur. 


\section{Sürekli Öfke-Öfke Tarz Ölçeği (SÖ-ÖTÖ)}

Ölçeğin orjinali Spielberger ve ark. (1985) tarafindan geliştirilmiş, Türkçe uyarlaması ise Özer (1994) tarafindan yapılmıştır 14,15. Ergen ve yetişkinlerde öfke düzeyini ve öfke ifade tarzlarını belirlemeye yönelik ölçek, toplam 34 maddeden oluşmaktadır. Ölçeğin yanıtlanmasında dörtlü derecelendirme (Hiç:1, Tümüyle: 4) kullanılmaktadır. Ölçekten toplam puan elde edilememekte, alt boyutlara göre puanlama yapılabilmektedir. Ölçeğin alt boyutlarından Sürekli Öfke (10 madde) boyutunda alınan yüksek puanlar öfke düzeyinin yüksek olduğunu yansitmaktadır. Öfke Kontrol (8 madde) puanının yüksekliği öfkenin kontrol edilebildiğini yansıtmaktadır. Bunun yanında Öfke Dışta (8 madde) boyutunda alınan yüksek puanlar öfkenin kolayca ifade edildiğini, Öfke İçte (8 madde) boyutunda alınan yüksek puanlar ise bastırılmış öfkeyi ifade etmektedir. Cronbach alfa katsayıları 'sürekli öfke' boyutu için 0,79 , 'öfke dişa vurumu' boyutu için 0,78 , 'öfke içe vurumu' boyutu için 0,62, 'öfke kontrolü' boyutu için 0,84 olarak bulunmuştur. Bu çalışmada ölçeğin Cronbach alfa değeri ise 0,82 , 'öfke dişa vurumu' boyutu için 0,81 , 'öfke içe vurumu' boyutu için 0,71 ve 'öfke kontrolü’ boyutu için 0,82 olarak belirlenmiştir.

\section{İstatistiksel analiz}

Elde edilen veriler SPSS 23 istatistiksel paket programıyla değerlendirilmiştir. Verilerin normal dağıllp dağılmadığa Kolmogorov-Smirnov testi ile değerlendirilmiş ve $\mathrm{p}<0,05$ olduğu için verilerin normal dağılmadığına karar verilmiştir. Bu nedenle, verilerin analizinde sayı, yüzde, ortalama, standart sapma, minimum ve maksimum değerler gibi tanımlayıcı istatistikler ile KBÇÖ ve SÖ-ÖTÖ arasındaki ilişkiyi değerlendirmek için Spearman korelasyon testi kullanılmıştır. İstatistiksel anlamlılık düzeyi $\mathrm{p}<0,05$ olarak kabul edilmiştir.

\section{BULGULAR}

Öğrencilerin \%47,6’s1 Anadolu Lisesi mezunu olup $\% 66,5$ 'i bölümlerini isteyerek tercih etmişlerdir. $\% 46,8$ 'inin annesi ve \%32,0'sinin babas1 ilkokul mezunu olup, \%85,4'ünün anneleri ev hanımı, $\% 38,2$ 'sinin babalar1 serbest meslek sahibidir. Öğrencilerin \% $\% 4,5$ 'i ailesinin gelir düzeyini ve $\% 66,7$ 'si kendi gelir düzeyini orta düzeyde tanımlamışlardır (Tablo 1).

Öğrencilerin yaklaşı üçte ikisinin (\%64,7) herhangi bir sosyal aktivitesi bulunmamaktadır. \%87,9'unun arkadaş grubu var iken sadece \%7,0'si yalnız olduğunu yani arkadaşı olmadığını ifade etmiştir. Arkadaşlık ilişkilerini öğrencilerin \%81,9’u iyi ve $\% 16,8$ 'i orta olarak tanımlamışlarken aile içi ilişkileri öğrencilerin \%81,1'i iyi ve \%17,5'i orta olarak tanımlamışlardır.

Araştırmaya katılan öğrencilerin ilişkilerle ilgili bilişsel çarpitmalar genel toplam puan ortalaması

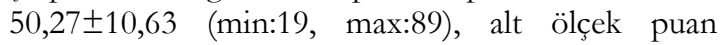
ortalamaları "yakınlıktan kaçınma" boyutunda

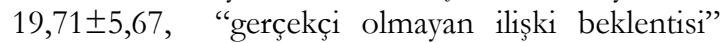
boyutunda $21,39 \pm 5,87$ ve "zihin okuma" boyutunda

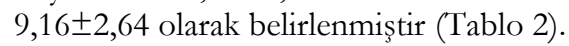

Öğrencilerin; sürekli öfke tarzı puan ortalaması

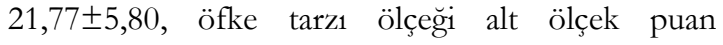
ortalamaları "kontrol altına alınmış öfke" boyutunda $22,76 \pm 4,70$, “dışa vurulan öfke" boyutunda $16,78 \pm 4,58$ ve "içte tutulan öfke" boyutunda 17,05 4,31 olarak saptanmıştır (Tablo 2).

Tablo 2. KBÇÖ ve SÖ-ÖTÖ puan ortalamaları

\begin{tabular}{|l|c|c|}
\hline & Ortalama & Min-Max \\
\hline Kişilerarası Bilişsel Çarpıtmalar Ölçeği & & $8-38$ \\
\hline Yakınlıktan kaçınma & $19.71 \pm 5.67$ & $8-38$ \\
\hline Gerçekçi olmayan ilişki & $21.39 \pm 5.87$ & $3-15$ \\
\hline Zihin okuma & $9.16 \pm 2.64$ & $19-89$ \\
\hline Toplam İ̈BÇÖ & $50.27 \pm 10.63$ & $10-40$ \\
\hline Sürekli Öfke-Öfke Tarz Ölçeği & & $8-32$ \\
\hline Sürekli öfke & $21.77 \pm 5.80$ & $8-32$ \\
\hline Kontrol altına alınmış öfke & $22.76 \pm 4.70$ & $8-30$ \\
\hline Dişa vurulan öfke & $16.78 \pm 4.58$ & \\
\hline İçte tutulan öfke & $17.05 \pm 4.31$ & \\
\hline
\end{tabular}


İlişkilere ilişkin bilişsel çarpıtma ölçeğinin yakınlıktan kaçınma alt boyutu ile sürekli öfke, dışa vurulan öfke ve içte tutulan öfke arasında orta düzeyde ve pozitif yönde bir ilişki belirlenmiştir $(p<0,05)$. Gerçekçi olmayan ilişki alt boyutu ile sürekli öfke, kontrol altına alınmış öfke, dışa vurulan öfke ve içte tutulan öfke arasında zayıf düzeyde ve pozitif yönde bir ilişki belirlenmiştir $(\mathrm{p}<0,05)$.
Zihin okuma alt boyutu ile kontrol altına alınmış öfke $(\mathrm{p}<0,05)$, sürekli öfke, dişa vurulan öfke ve içte tutulan öfke arasında zayıf düzeyde ve pozitif yönde bir ilişki belirlenmiştir $(\mathrm{p}<0,05)$. KBÇÖ'nün toplam puanları ile sürekli öfke, dişa vurulan öfke ve içte tutulan öfke arasinda orta düzeyde ve pozitif yönde bir ilişki belirlenmiştir $(p<0,05)$.

Tablo 3. KBÇÖ ve SÖ-ÖTÖ arasındaki korelasyona ilişkin bulgular

\begin{tabular}{|l|l|c|c|c|c|}
\hline \multicolumn{2}{|c|}{} & Sürekli öfke & $\begin{array}{c}\text { Kontrol altına } \\
\text { alınmış öfke }\end{array}$ & $\begin{array}{c}\text { Dişa vurulan } \\
\text { öfke }\end{array}$ & $\begin{array}{c}\text { İçte tutulan } \\
\text { öfke }\end{array}$ \\
\hline Yakınlıktan kaçınma & $\mathrm{r}$ & 0.451 & -0.084 & 0.448 & 0.471 \\
\cline { 2 - 6 } & $\mathrm{p}$ & 0.000 & 0.064 & 0.000 & 0.000 \\
\hline Gerçekçi olmayan ilişki & $\mathrm{r}$ & 0.260 & 0.123 & 0.132 & 0.286 \\
\cline { 2 - 6 } & $\mathrm{p}$ & 0.000 & 0.007 & 0.004 & 0.000 \\
\hline Zihin okuma & $\mathrm{r}$ & 0.169 & 0.103 & 0.150 & 0.137 \\
\cline { 2 - 6 } & $\mathrm{p}$ & 0.000 & 0.023 & 0.001 & 0.002 \\
\hline Toplam İ̈BÇÖ & $\mathrm{r}$ & 0.429 & 0.043 & 0.000 & 0.443 \\
\cline { 2 - 6 } & $\mathrm{p}$ & 0.000 & 0.347 & & 0.000 \\
\hline
\end{tabular}

\section{TARTIŞMA}

$\mathrm{Bu}$ çalışmada öğrencilerin ilişkilerle ilgili bilişsel çarpitmalar genel toplam puan ortalamasi 50,27 $\pm 10,63$ olarak belirlenmiştir. Öğrencilerin ilişkkilerle ilgili bilişsel çarpıtma puanlarının yüksek olmadığ1 görülmektedir. Konuyla ilgili yapılan çalışmalarda da benzer puanlar elde edilmiştir. Bilişsel çarpitmalar genel toplam puan ortalamasının; Kuzucu ve arkadaşlarının üniversite öğrencileriyle yaptıkları

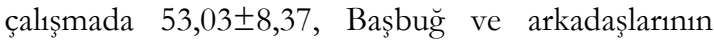
üniversite ögrencileriyle yaptıkları çalışmada $51,02 \pm 9,98$ ve Koydemir ve Demir'in üniversite

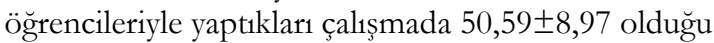
belirlenmiştir 9,16,17. Bu çalışmaya katılan öğrencilere göre, Çoban'ın çalışmasina katılan öğrencilerin "yakınlıktan kaçınma" boyutunda daha iyi bilişsel yapıya sahip oldukları, "gerçekçi olmayan ilişki beklentisi" ve "zihin okuma" boyutlarında ise daha fazla bilişsel çarpıtmaya sahip oldukları belirlenmiştir 18. Elde edilen bulgular doğrultusunda, bu araştırmaya katılan öğrencilerin ilişkilere ilişkin çok fazla bilişsel çarpıtmalara sahip olmadığı, genel anlamda değerlendirildiğinde, ilişkilerinde yakınlık kurarlarsa zarar görmekten korkma, ilişkilerinde yüksek beklenti içinde olma ve karşısındaki bireyin zihnini okumaya çalışma puanlarının orta düzeyde olduğu ve bu düzeyin psikolojik yardım alma bağlamında ciddi bir sorun oluşturmadığı söylenebilir.
Çalışmaya katılan öğrencilerin sürekli öfke tarzı puan ortalamalarının $21,77 \pm 5,80$ olduğu saptanmıştır. Sürekli öfke tarzı puan ortalamasının; Akdeniz ve arkadaşlarının spor ve eğitim bilimleri öğrencileri ile

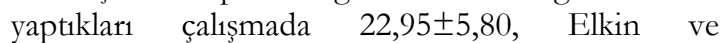
Karadağlı'nın sağlık bilimleri öğrencileri ile yaptıkları

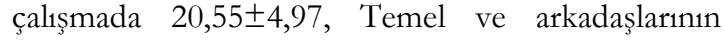
sportif rekreasyon etkinliklerine katılan erkek üniversite öğrencileriyle yaptıkları çalışmada

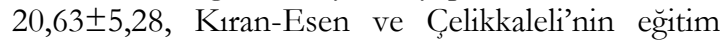
bilimleri öğrencileri ile yaptıkları çalışmada

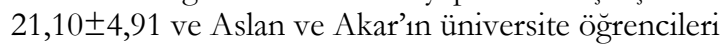

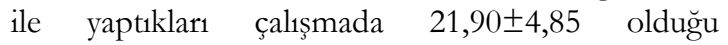
belirlenmiştir ${ }^{19-23}$. Bu sonuçlara göre araştırmaya katılan ögrencilerin öfke puanlarının orta düzeyde olduğu ve literatür ile paralellik gösterdiği söylenebilir.

$\mathrm{Bu}$ araştırmada öğrencilerin ilişkilere ilişkkin bilişsel çarpıtmaları ile sürekli öfke, dışa vurulan öfke ve içte tutulan öfke puanları arasında orta düzeyde ve pozitif yönde bir ilişki olduğu belirlenmiştir. Uğur ve Murat'ın lise öğrencilerinde yaptı̆̆1 çalışmada, kişiler arası ilişkilerle ilgili bilişsel çarpıtmaları olan öğrencilerin öfke ve düşmanlık duygularını daha çok yaşadıkları, fiziksel, sözel ve dolaylı saldırganlık düzeylerinin ise daha yüksek olduğu belirlenmiştir ${ }^{24}$. Benzer şekilde Gündoğdu ve arkadaşlarının çalışmasında, romantik ilişkilerle ilgili irrasyonel düşünceleri olan üniversite öğrencilerinin 
olmayanlara göre daha agresif oldukları ifade edilmiştir 25. Çelikkaleli ve Kaya'nın üniversite öğrencilerinde yaptıkları çalışmada, ilişkilerle ilgili bilişsel çarpıtmaların kişilerin duygusal yetkinlik inancinı etkilediği, yani öfke gibi pek çok duyguyu yönetebilme algısını olumsuz etkilediği bildirilmiştir 26. Dolayısıyla, ilişkilerle ilgili sahip olunan bilişsel çarpıtmaların öğrencilerin öfke düzeylerini ve öfkeyi ifade etme biçimlerini olumsuz etkilediği söylenebilir.

Araştırmaya katılan öğrencilerin ilişkilerle ilgili bilişsel çarpıtmaları ile öfke ifade tarzları arasında önemli bir ilişki belirlenmiştir. Başka bir deyişle, ilişkilerinde yakınlıktan kaçınan, gerçekçi olmayan beklentileri olan ve zihin okuyan öğrencilerin öfkelerini kontrol altına almakta zorlandıkları ve sürekli öfke yaşadıkları söylenebilir. Öfkesini yönetemeyen öğrenci, günlük yaşamında pek çok sorunla karşı karşıya kalabilir ve bu sorunları etkili bir biçimde yönetemeyebilir. Nitekim yapılan çalışmalar, öfkesini etkili bir biçimde yönetemeyen öğrencilerin kişilerarası ilişkilerinden doyum alamadıklarını ve yaşanan doyumsuzluğun sonucunda yalnız kaldıklarını, üniversite yaşamına sosyal olarak uyum sağlayamadıklarını, benlik saygılarının zedelenerek depresyon gibi ruhsal sorunlar yaşadıklarını belirlemişlerdir 11,27,28. Bu sonuçlar doğrultusunda, öğrencilerin öfkelerini etkin bir biçimde yönetebilmeleri için sağlıklı ilişkiler kurabilmeleri, kurdukları ilişkileri sağlıklı bir biçimde yönetebilmeleri ve yakın ilişkilerle ilgili sağlıklı düşünce ve inançlara sahip olmaları gerektiği söylenebilir.

Araștırmanın bazı kısıtlılıkları bulunmaktadır. Bu araştırma, bir devlet üniversitesinde okuyan hemşirelik ve sağllk yönetimi öğrencileri ile yürütüldüğü için araştırmanın sonuçları, diğer devlet üniversitelerinde ve özel üniversitelerde okuyan hemşirelik ve sağlik yönetimi öğrencilerine genellenemez. Araştırmanın diğer bir kısıtlılığı, araştırma sonuçlarının katılımcıların bildirimlerine dayandırılmış olmasıdır.

Sonuç olarak, bu araştırmaya katılan hemşirelik ve sağl1k yönetimi öğrencilerinin ilişkilere ilişkin bilişsel çarpıtmaları ile sürekli öfke ve öfke tarzı puanlarının orta düzeyde olduğu; ayrıca öğrencilerin ilişkilere ilişkin bilişsel çarpıtmaları ile sürekli öfke, dışa vurulan öfke ve içte tutulan öfke puanları arasında orta düzeyde ve pozitif yönde bir ilişki olduğu belirlenmiştir. Bir başka deyişle, öğrencilerin ilişkilerle ilgili bilişsel çarpıtmaları arttıkça öfke düzeyleri de artış göstermektedir. Bu duruma bağlı olarak ögrenciler öfke yönetimiyle ilgili sorunlar yaşamaktadır. $\mathrm{Bu}$ bulgular 1şı̆̆ında, öncelikle öğrencilerin hem ilişkilerle ilgili bilişsel çarpıtmalarının hem de öfke yönetim tarzlarının belirlenmesi önerilmiştir. İlişkilerle ilgili sağlıklı bilişsel bir yapıya sahip olmayan öğrencilerin ve öfkesini etkili bir biçimde yönetemeyen öğrencilerin uygun bir psikolojik yardım ya da danışmanlık almaları için yönlendirilmeleri önemlidir. Bu bağlamda, öğrencilere öfkelerini yönetebilmeleri ve kişilerarası ilişkilerle ilgili yaşadıkları bilişsel çarpıtmalardan kurtulabilmeleri için bilişseldavranışçı terapi programlarının veya bilinçli farkındalık temelli danışmanlık programlarının uygulanması önerilmiştir.

This study is accepted as an oral presentation at the 1st Congress of Cognitive Behavioral Psychotherapies, Ankara, Turkey, October 18-21, 2018.

Yazar Katkıları: Çalışma konsepti/Tasarımı: AY; Veri toplama: AY; Veri analizi ve yorumlama: EBY; Yazı taslağı: EBY; İçeriğin eleștirel incelenmesi: EBY; Son onay ve sorumluluk: AY, EBY; Teknik ve malzeme desteği: AY; Süpervizyon: AY; Fon sağlama (mevcut ise): yok. Bilgilendirilmiş Onam: Katılımcılardan yazılı onam alınmıştır.

Hakem Değerlendirmesi: Dış bağımsız.

Cı1kar Çatışması: Yazarlar çıkar çatışması beyan etmemişlerdir. Finansal Destek: Yazarlar finansal destek beyan etmemişlerdir. Yazarın Notu: Bu çalışma, 1. Bilişsel Davranış Psikoterapileri Kongresi'nde, 18-21 Ekim 2018, Ankara'da sözlü sunum olarak sunulmuștur.

Author Contributions: Concept/Design : AY; Data acquisition: AY; Data analysis and interpretation: EBY; Drafting manuscript: EBY; Critical revision of manuscript: EBY; Final approval and accountability:

AY, EBY; Technical or material support: AY; Supervision: AY; Securing funding (if available): $\mathrm{n} / \mathrm{a}$.

Informed Consent: Written consent was obtained from the participants.

Peer-review: Externally peer-reviewed.

Conflict of Interest: Authors declared no conflict of interest.

Financial Disclosure: Authors declared no financial support

Acknowledgment: This study is presented as an oral presentation at

the 1st Congress of Cognitive Behavioral Psychotherapies, Ankara, Turkey, October 18-21, 2018

\section{KAYNAKLAR}

1. Doğan O. Sağlık Bilimleri Alanında Davranış Bilimleri, Sivas, Cumhuriyet Üniversitesi Yayınları (No:76), 1999.

2. Addis J, Bernard ME. Marital adjustment and irrational beliefs. J Ration Emot Cogn Behav Ther. 2002;20:3-13.

3. Zhang LF. Cognitive distortions and autonomy among Chinese university students. Learn Individ Differ. 2008;18:279-84.

4. Demirtaş-Zorbaz S, Ulas Ö, Kepir-Savoly DD. University student's relationship's believes: sample of Turkey. Procedia Soc Behav Sci. 2015;185:495-9.

5. Filipovic S, Vukosavljevic-Gvozden T, Opacic G. Irrational beliefs, dysfunctional emotions and marital 
adjustment: a structural model. J Fam Issues. 2016;37:2333-50.

6. Beck JS. Bilişsel Terapi: Temel İlkeler ve Ötesi (Çeviri Eds N Hisli-Şahin, F Balkaya, Aİ Koçkar). Ankara, Türk Psikologlar Derneği Yayınları (No:22), 2001.

7. Hiçdurmaz D, Öz F. Benliğin bilişsel yaklaşımla güçlendirilmesi. Sağlık Bilimleri Fakültesi Hemşirelik Dergisi. 2011;68-78.

8. Öncü B, Sakarya A. Ergen özkıyımlarında bilişsel etmenler ve çarpitmaların rolü. Psikiyatride Güncel Yaklaşımlar. 2013;5:232-45.

9. Kuzucu Y, Tunçer İ, Aksu Ş. İlişkilerde bilişsel çarpıtmalar ve öz-kontrol ilișkisinde sürekli öfkenin aracilık rolü. Journal of Educational Sciences. 2015;6:48-56.

10. Ogai H. Cognitive distortions in interpersonal situation and stress responses of nursing students. J Jpn Acad Nurs Sci. 2013;33:21-8.

11. Kaya N, Kaya H, Yalçın-Atar N, Turan N, Eskimez Z, Palloş A, et al. Hemşirelik ve ebelik öğrencilerinin öfke ve yalnızlık özellikleri. Hemşirelikte Eğitim ve Araştırma Dergisi. 2012;9:18-26.

12. Saraç A, Hamamc1 Z, Güçray S. Üniversite öğrencilerinin romantik ilişki doyumunun yordanması. Türk Psikolojik Rehberlik ve Danışma Dergisi. 2015;5:69-81.

13. Hamamcı Z, Büyüköztürk Ş. İlişkilerle ilgili bilişsel çarpıtmalar ölçeği: ölçeğin geliștirilmesi ve psikometrik özelliklerinin incelenmesi. Çukurova Üniversitesi Eğitim Fakültesi Dergisi. 2003;2:107-11.

14. Spielberger CD, Johnson EH, Russell SF, Crane RJ, Jacobs GA, Worden TJ. The experience and expression of anger: construction and validation of an anger expression scale, In Anger And Hostility in Cardiovascular And Behavioral Disorders (Eds MA Chesney, RH Rosenman):5-30. New York, Hemisphere, 1985.

15. Özer AK. Sürekli öfke (SL-Öfke) ve öfke ifade tarzı (Öfke-Tarz) ölçekleri ön çalışması. Türk Psikoloji Dergisi. 1994;9:26-35.

16. Başbuğ S, Cesur G, Durak-Batıgün A. Algılanan ebeveynlik biçimi ve yetişkin ayrılma anksiyetesi: kişilerarası bilişsel çarpıtmaların aracı rolü. Turk Psikiyatri Derg. 2017;28:255-67.
17. Köydemir S, Demir A. Shyness and cognitions: an examination of Turkish university students. J Psychol. 2008;142:633-44.

18. Çoban AE. Interpersonal cognitive distortions and stress coping strategies of late adolescents. Eurasian Journal of Educational Research. 2013;51:65-84.

19. Akdeniz H, Demirci D, Sekban G, Yurtsever Y. Üniversite öğrencilerinin öfke düzeylerinin karşılaştırılması (Kocaeli üniversitesi örneği). Muş Alparslan Üniversitesi Uluslararas1 Spor Bilimleri Dergisi. 2017;1:46-60.

20. Elkin N, Karadağlı F. Üniversite öğrencilerinin öfke ifade tarzı ve ilişkili faktörler. Anadolu Clin. 2016;21:64-71.

21. Temel V, Birol SȘ, Akpınar S, Nas K. Öğrencilerin karar verme düzeyleri ile sürekli öfke ve öfke ifade tarzlarının belirlenmesi. The Journal of International Anatolia Sport Science 2017;3:122-32.

22. Kıran-Esen B, Çelikkaleli Ö. Üniversite öğrencilerinin sosyal yetkinlik düzeyleri ile sürekli öfke ve öfke ifade biçimlerinin belirlenmesi. Türk Psikolojik Danışma ve Rehberlik Dergisi. 2016;3:37-49.

23. Aslan N, Akar H. Üniversite öğrencilerinde öfke ifade tarzları ile mizaç ve karakter özellikleri arasındaki ilişki. Düşünen Adam. 2016;29:120-8.

24. Uğur E, Murat M. Lise öğrencilerinin kişiler arası ilişkilerle ilgili bilişsel çarpıtmaları ve saldırganlık tepkileri arasındaki ilişkinin incelenmesi. Gaziantep University Journal of Social Sciences. 2014;13:525-43.

25. Gündoğdu R, Yavuzer Y, Karataş Z. Irrational beliefs in romantic relationships as the predictor of aggression in emerging adulthood. Journal of Education and Training Studies. 2018;6:108-15.

26. Celikkaleli Ö, Kaya S. University students' interpersonal cognitive distortions, psychological resilience, and emotional self-efficacy according to sex and gender roles. Pegem Eğitim ve Öğretim Dergisi. 2016;6:187-212.

27. Hamamc1 Z, Esen-Çoban A. Dysfunctional relationship beliefs of late adolescence in adjustment to university. Procedia Soc Behav Sci. 2010;2:300-4.

28. Cha NH, Sok SR. Depression, self-esteem and anger expression patterns of Korean nursing students. Int Nurs Rev. 2014;61:109-15. 